\title{
Problems of the preliminary customs informing system and the introduction of the Single Window at the sea check points of the Russian Federation
}

\author{
Svetlana Maydanova ${ }^{1 *}$, Igor Ilin $^{2}$ \\ ${ }^{1}$ Unifeeder A/S, branch in St.-Petersburg, Russia \\ ${ }^{2}$ Peter the Great St.Petersburg Polytechnic University, Polytechnicheskaya, 29, St. Petersburg, 195251, \\ Russia
}

\begin{abstract}
The Single Window concept in the international trade and logistics has been explored by international organizations and national governments over the last two decades. International standards and recommendations, government decisions on this approach are widespread today in both developed and developing countries. Similar decisions and legal acts were implemented during the last ten years by the Russian Federation, as a member of the Eurasian Economic Union. This article provides overview of the following coherent stage - the implementation of preliminary customs informing system at sea check points of the RF with concerns of the Single Window introduction.
\end{abstract}

\section{Introduction}

The entry into force of the new the Eurasian Economic Union Customs code will lead to transition of customs authority procedures to modern information technologies. In particular, the Customs code allows submitting preliminary information to the customs authorities in electronic format. The chance to use e-documents for the public authority submissions is an additional incentive for the mechanism of the EEU Single Window development [1]. In compliance with [2] the mechanism of a Single Window is created "for effective information exchange between trade organizations and public authorities" (B2G). Implementation and utilization of the Single Window could bring benefits to public authorities, and to the business.

The Single Window implementation is especially important for the improvement of the marine transport state control procedures at sea check points in order to reduce cargo handling delays and unproductive vessels idle time. Besides, the Single Window introduction at border check points is an effective tool for the coordinated management of the border, which allows improving significantly quality of all state control procedures on the border with reduced time and financial spending.

\footnotetext{
* Corresponding author: sma@unifeeder.com
} 


\section{Literature Review}

Within the context of [2], a Single Window is defined as a facility that allows parties involved in trade and transportation lodging standardized information and documents with a singleentry point to comply with all import, export, and transit-related regulatory requirements. If information is electronic, then individual data elements should only be submitted once.

In accordance with [2] the introduction of the Single Window will provide the following benefits for the Government:

1) More effective and efficient deployment of resources;

2) Correct (and often increased) revenue yield;

3) Improved trader compliance;

4) Enhanced security;

5) Increased integrity and transparency.

The introduction of the Single Window will provide the following benefits for the Business:

1) Cutting costs through reduced delays;

2) Faster clearance and release;

3) Predictable application and explanation of rules;

4) More effective and efficient deployment of resources;

5) More transparency.

For the unification of Single Window approaches in 2010-2012, a set of special managerial guidelines by The United Nations Network of Experts for Paperless Trade and Transport in Asia and the Pacific (UNNExT) was issued in cooperation with such organizations as the Economic and Social Commission for Asia and the Pacific, United Nations Economic Commission for Europe, World Customs Organization.

The experience of Single Window creation was generalized, evolutionary stages and frame bases of creation at the national and regional levels were designated. Although the national Single Window systems are created step by step, gradually changing during long time, five main levels of their evolutionary development can be defined [3]. They could be used as a basis for the long-term strategic plan for the implementation of a national Single Window:

Level 1: A Paperless Customs. Development of paperless customs declaration system.

Level 2: A regulatory Single Window. Integration of Paperless Customs with other regulatory bodies issuing trade/import/export/transit-related permits and certificates, and other related documents.

Level 3: A Port Single Window or B2B Port Community System. Extension of the Single Window to serve entire trade and logistics communities within airports, seaports and/or dry ports.

Level 4: A fully Integrated Single Window. Creation of an integrated national logistics platform interlinking the administrations, companies and the service sectors to better manage the entire chain of import-export operations.

Level 5: A Cross-border Single Window Exchange Platform. Interconnection and integration of national single windows into a bi-lateral or regional cross-border e-information exchange platform.

The Single Window functionality is significantly broader than the preliminary submission of information to the customs authorities, it is very important for all government agencies at the border, and the use of the Single Window for the development of preliminary informing has several advantages in comparison to the use of the custom authority information systems.

The international experience and recommendations $[2,3,4,5,6]$ demonstrate expediency of preliminary informing development at sea check points, including by means of the Single Window for the submission of preliminary information not only to the customs authorities, 
but also to all other government agencies at sea check points, for the creation of integrated risk management system and the coordinated management of the border.

The Supreme Eurasian Economic Council approved development of Single Window in the foreign economic activity regulation system in the EEU territory on May 29, 2014, the introduction of the Single Window in the Russian Federation has been repeatedly discussed at international scientific and practical conferences, however no legal basis to provide for a Single Window functioning is available in the Russian Federation. At this stage, the legal base is developed only for the preliminary informing procedure $[7,8,9,10,11,12,13]$. The entry into force of the new EEU Customs code [7] from January 01, 2018 has led to the increased importance of amending the national legislation for members of the Union, however to introduce the EEU Customs code and the Federal Law "On Customs Regulation" [8] in the Russian Federation in full, it is required to develop and adopt hundreds of regulatory documents.

\section{Metodology}

The authors have studied the available materials on the Single Window and preliminary informing system introduction, the results of the KPS Portal Seaport implementation and possibilities of the Single Window use at the sea check points of the RF.

The models of cargo import process were developed with the enterprise architecture modeling language Archimate 3.0 and the Archi ${ }^{\circledR}$ modeling tool.

\section{Results}

In general, the following obligatory characteristics are inherent for the Single Window:

1) Existence of a Single Authority that receives information, either on paper or electronically, disseminates this information to all relevant governmental authorities, and co-ordinates controls to prevent undue hindrance in the logistical chain;

2) Existence of a single-entry point for information exchange between the government agencies and business (B2G);

3) A single submission and repeated use of the data transferred through single-entry point;

4) A uniform standard format of data elements (uniform data model).

The preliminary informing procedure in seaports is a procedure of providing data about goods and vessels to the customs authorities before their actual arrival to the Customs union territory. [14]

The essential differences between the "preliminary informing" and the Single Window are presented in the table [14]:

Table 1. Comparison of the preliminary customs informing system and the Single Window

\begin{tabular}{|c|c|c|c|}
\hline & Feature & Preliminary informing & "Single Window" \\
\hline 1 & $\begin{array}{l}\text { Receiver of the } \\
\text { information }\end{array}$ & Customs authorities & The Single Authority \\
\hline 2 & $\begin{array}{l}\text { Single-entry } \\
\text { point }\end{array}$ & $\begin{array}{l}\text { Obtaining information for } \\
\text { the customs authorities does not } \\
\text { release the sender from } \\
\text { responsibility for delivery of } \\
\text { information to other government } \\
\text { agencies through other information } \\
\text { systems }\end{array}$ & $\begin{array}{l}\text { The Single Authority provides access } \\
\text { to data not only for the customs } \\
\text { authorities, but also for other } \\
\text { government agencies. A set of } \\
\text { government agencies information } \\
\text { systems is replaced with the Single } \\
\text { Window }\end{array}$ \\
\hline
\end{tabular}




\begin{tabular}{|l|l|l|l|}
\hline 3 & $\begin{array}{l}\text { Single data } \\
\text { submission }\end{array}$ & $\begin{array}{l}\text { Preliminary information submission } \\
\text { does not release carriers from the } \\
\text { requirement of repeated } \\
\text { data submissions upon arrival of the } \\
\text { vehicle (vessel) or cargo }\end{array}$ & $\begin{array}{l}\text { A single data submission by carriers is } \\
\text { implemented, reports about actual } \\
\text { vessel arrival are submitted by the } \\
\text { Maritime Administration }\end{array}$ \\
\hline 4 & $\begin{array}{l}\text { Uniform } \\
\text { standard format } \\
\text { of data elements }\end{array}$ & $\begin{array}{l}\text { Format of data representation } \\
\text { depend on the existing customs } \\
\text { authority information systems }\end{array}$ & $\begin{array}{l}\text { A possibility of information } \\
\text { acceptance from the maximum } \\
\text { quantity of sources in all possible } \\
\text { formats is implemented }\end{array}$ \\
\hline 5 & $\begin{array}{l}\text { Application of } \\
\text { the } \\
\text { international } \\
\text { electronic data } \\
\text { exchange } \\
\text { standards }\end{array}$ & $\begin{array}{l}\text { The customs authorities } \\
\text { information systems need to be } \\
\text { upgraded for the reception of data } \\
\text { based on international } \\
\text { standards }\end{array}$ & $\begin{array}{l}\text { A single solution is deployed with } \\
\text { data reception, based on international } \\
\text { standards, and } \\
\text { transforming them to the general } \\
\text { format for all government agencies }\end{array}$ \\
\hline 6 & $\begin{array}{l}\text { Resource } \\
\text { savings }\end{array}$ & $\begin{array}{l}\text { Institutional system of the customs } \\
\text { authorities }\end{array}$ & $\begin{array}{l}\text { Interinstitutional system of } \\
\text { government agencies }\end{array}$ \\
\hline 7 & $\begin{array}{l}\text { Preliminary information } \\
\text { management of } \\
\text { border }\end{array}$ & $\begin{array}{l}\text { Single Window data is the basis for } \\
\text { risk management system of the } \\
\text { border customs authorities }\end{array}$ & $\begin{array}{l}\text { functioning of all government } \\
\text { agencies risk management systems. } \\
\text { An integrated risk management } \\
\text { system for coordinated } \\
\text { management of border can be } \\
\text { implemented }\end{array}$ \\
\hline
\end{tabular}

Preliminary Informing (PI) in the EEU is already obligatory on railway, motor and air transport, the procedure for the preliminary informing at sea check points is obligatory only in the territory of the Free port of Vladivostok.

Preliminary information for cargo water transportation could be provided by both the carrier or a person acting on its behalf and (or) other interested person having the right to dispose of goods. For this purpose, the KPS Portal Seaport is used in the territory of the Russian Federation. It was developed for FCS of Russia and was created as "a system to provide electronic interaction of all participants of the goods and vehicles registration process at sea check points, aimed at creating favorable conditions for commodity turnover acceleration across the customs border of the Eurasian Economic Union (EEU), reduced time for the customs commission operations, and increased customs control efficiency". The KPS Portal Seaport is the communication platform providing information exchange of the international shipping participants, interaction of the public control authorities (PCA) and related persons in the goods and vehicles registration process at sea check points. While using the KPS Portal Seaport, foreign trade activity participants submit to customs authority preliminary information about the goods, and carriers - about the sea vessel prior to arrival at the port. This data could be used by other government agencies to define the forms of veterinary, phytosanitary and sanitary, and border control.

According to the statistics from the FCS of Russia, the introduction of obligatory preliminary informing about the goods, arriving by marine transport in the territory of the free port of Vladivostok since October 1, 2016 has allowed to reduce the average time of container handling from the moment of unloading to the state control approval from 6,5 to 5,5 days. Also, the average time of the release of goods by the customs authorities was reduced almost by half [15].

In 2017, the customs officials of Baltic customs post have developed the new interaction procedure, providing the actual control of goods via KPS Portal Seaport on the principle "uniform check in one place". It means that after the submission of the preliminary information, in case of actual control requirements, all controlling actions are conducted at 
the same time not only by the custom authorities, but by other government agencies as well [16].

As the Administration of the Baltic Sea Ports has noted, application of the KPS Portal Seaport by the Baltic customs and the "Big Port St. Petersburg" Administration has positively influenced on customs commission operations concerning merchant ships and allowed improving the information exchange efficiency within the approved scheme of the RF state border admission. The application of the KPS Portal Seaport has already allowed the port administration submitting information about the forthcoming vessel calls to the customs and other government agencies on a daily basis. Also, any changes in the data are promptly submitted to all government agencies. Function of direct exchange with state port control information system is implemented through the KPS Portal Seaport [16]. See Fig.1 for a model of cargo imports to the EEU territory at the RF sea check points.

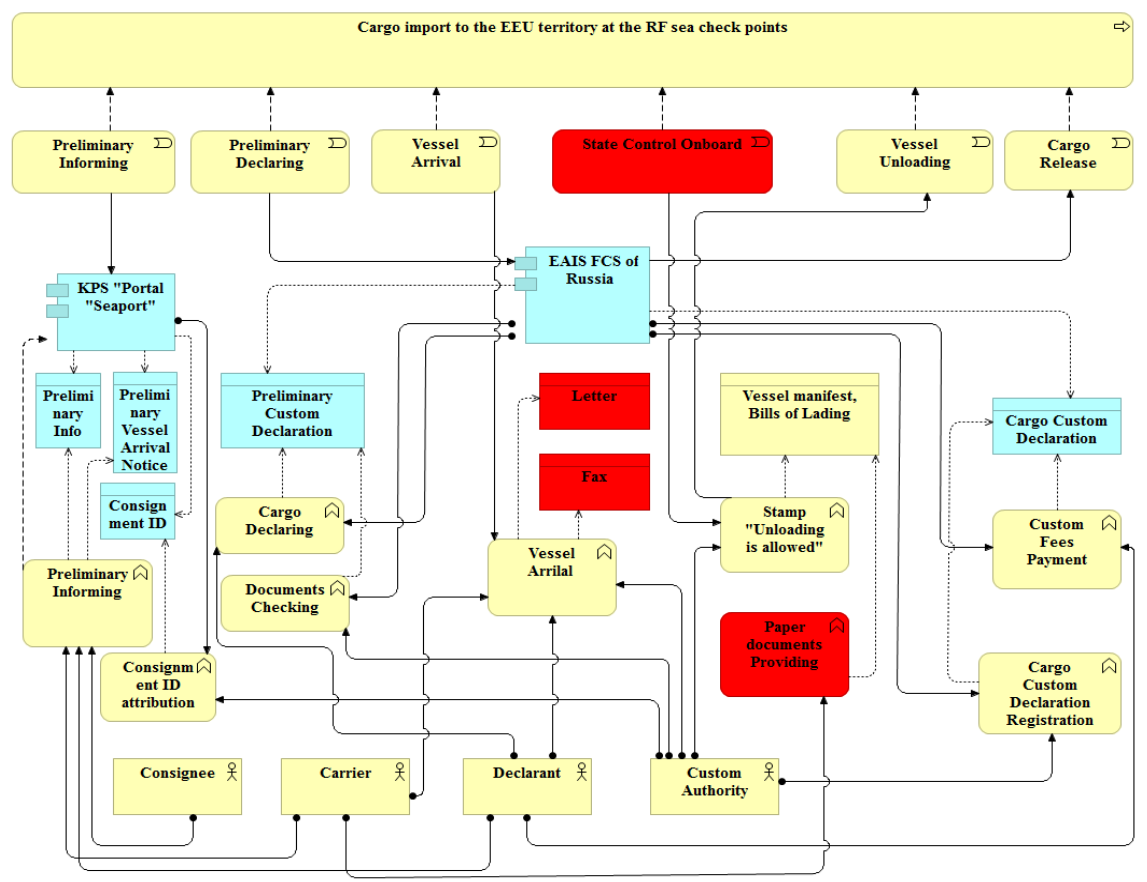

Fig. 1. Cargo import to EEU territory at the RF sea check points model as is.

However, along with some positive effect from introduction of KPS Portal Seaport and preliminary informing of the customs authorities, there is a number of unresolved issues related to the cargo import registration at sea check points:

1) According to the EEU Customs code, the carrier is obliged to give preliminary information in 6 hours prior to the vessel arrival and to receive consignment ID code from customs. Receiving this code has no any value for cargo operations, and after the vessel arrival the carrier has to report the arrival to the customs once again.

2) The data format of the KPS Portal Seaport differs from the international data standard UN/EDIFACT developed in 1987 by the UN and the approved ISO standard for application in the field of administration, commerce and transport, that results in a requirement for manual entry of large amounts of information.

3) The KPS Portal Seaport allows providing preliminary information about the goods (PI), based on the preliminary declaration of goods (PCD). However, the preliminary informing process and cargoes preliminary declaring process are not 
interconnected processes, the data travels in various systems several times and is regulated by various instructions. Without accurate regulations of preliminary informing and preliminary declaring processes it is impossible to use preliminary work advantages.

4) After the vessel arrival notice, the carrier in the Russian port has to wait for commission onboard to submit paper documents for the customs inspector. And only then it is possible to begin the cargo operations - the vessel unloading.

5) The customs authorities information system is not capable to match container numbers from vessel shipping documents with PI numbers and the goods description, provided by consignees / customs declarants that leads to information duplication in various systems.

The conducted research allows for the conclusion that the KPS Portal Seaport at its current stage should be considered as a Single Window pilot project. The Single Window model of cargo import to the EEU territory at the RF sea check points is shown on Fig. 2.

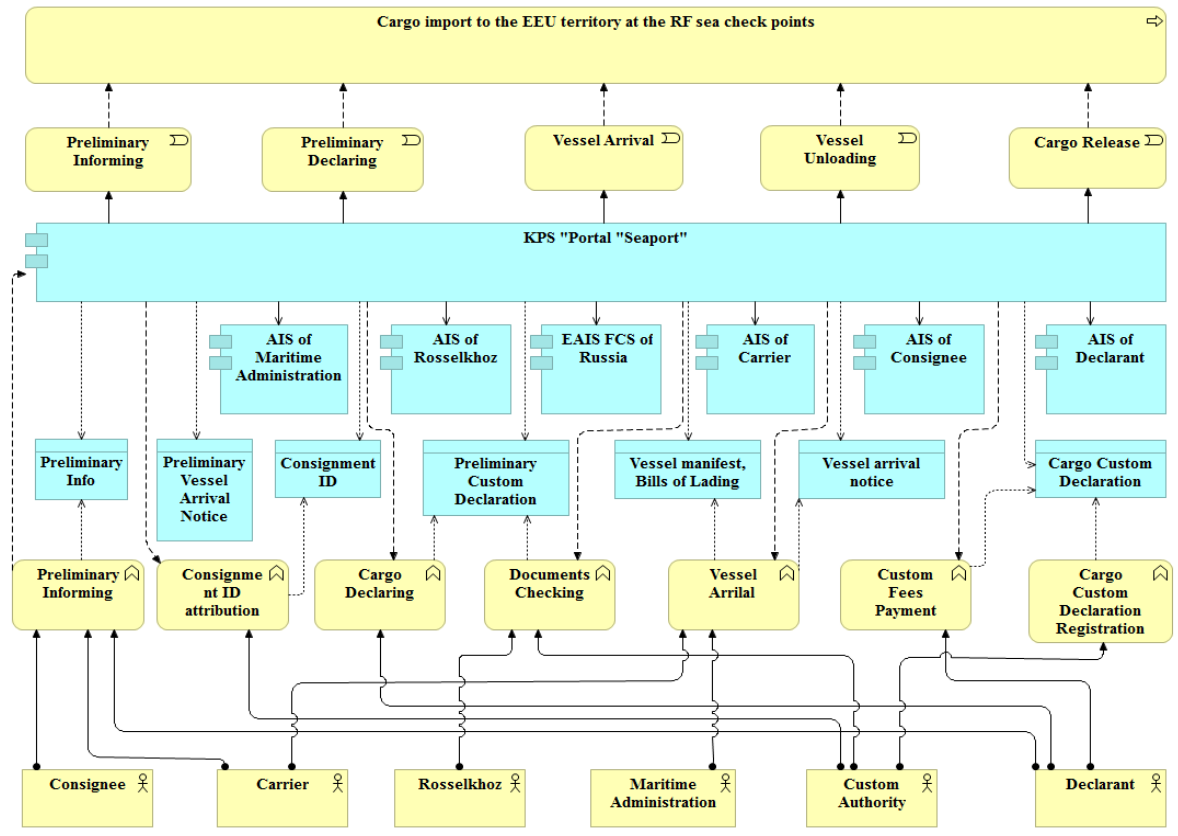

Fig. 2. The Single Window model for cargo import to the EEU territory at the RF sea check points.

According to the expert estimates [18], the KPS Portal Seaport has now the following advantages which will allow implementing the Single Window subsequently:

1) It is the only software product now, which makes it possible to refuse paper in the relationship between shipowners and customs.

2) The KPS Portal Seaport remains so far the only software product which allows releasing goods which have arrived by the marine transport before their actual unloading on the port constant customs control zone (CCCZ) territory as it is offered by item 19.14 of the Road Map [17].

3) By means of the KPS Portal Seaport, the experiment on single check of goods and documents by all government agencies is made (item 31.14 of the Road Map) [17].

4) Unlike the numerous systems of interdepartmental electronic interaction, the KPS Portal Seaport have an important advantage: the user understands the status of goods and decisions made by any supervisory authority. 
According to [2], the Single Window should be managed by a leading agency enabling the appropriate governmental authorities and agencies to receive or have access to the information, relevant for their purpose. Practically all main departments - the Ministry of Economic Development, the Ministry of Telecom and Mass Communications, the Ministry of Transport and so on are responsible for the development of the Single Window in the Russian Federation. It leads to losing coordination between the project participants. If a customs authority is considered as the leading agency (according to the UN data, in $80 \%$ of cases it is an authorized body, responsible for the implementation of the Single Window), then for rendering the necessary stimulating impact on other government agencies it lacks the powers available.

\section{Conclusion}

Development of the Single Window, based on preliminary information submission not only to the customs authorities, but also to all other government agencies at sea check points would provide the possibility of coordinated management of the border and creation of the integrated risk management system, and it could also reduce cargo handling delays and unproductive vessel idle time. Nowadays KPS Portal Seaport is launched for preliminary customs informing in the territory of the Russian Federation, which, subject to appropriate funding, a leading agency responsible for its development, and application of the modern unified approaches established by the international standards and recommendations, will allow subsequent implementing of the Single Window for simplification of the international trade procedures at sea check points of the Russian Federation.

\section{References}

1. URL: $\underline{\text { https://docs.eaeunion.org }}$

2. United Nations Centre for Trade Facilitation and Electronic Business Recommendation N33. Recommendation and Guidelines on establishing a Single Window to enhance the efficient exchange of information between trade and government (2005, July). ISBN 92-1-116924-0

3. Economic and Social Commission for Asia and Pacific. Single Window Planning and Implementation Guide (2013). Retrieved from https://www.unescap.org/ resources/single-window-planning-and-implementation-guide

4. United Nations Centre for Trade Facilitation and Electronic Business Recommendation №35. Establishing a Legal Framework for International Trade Single Window (2010, December). Retrieved from http://www.unece.org/ fileadmin/DAM/cefact/recommendations/rec35/Rec35_ECE_TRADE_401_Establishi ngLegalFrameworkforSingleWindow_E.pdf

5. United Nations Centre for Trade Facilitation and Electronic Business Recommendation №36. Single Window Interoperability (2017). Retrieved from http://www.unece.org/fileadmin/DAM/trade/Publications/ECE-TRADE431E_Rec36.pdf

6. WCO Compendium How to build a Single Window Environment (2011). Retrieved from http://www.wcoomd.org/en/topics/facilitation/instrument-and-tools/tools/singlewindow-guidelines.aspx

7. Eurasian Economic Union Customs code (2018, January 1). Retrieved from http://www.eaeunion.org/ 
8. Russian Federal Law No311-FZ "On Customs Regulation in RF" (2010, November 27). Retrieved from http://www.pravo.gov.ru

9. FCS of Russia. The order No1787 (2010, September 28). Retrieved from http://www.pravo.gov.ru

10. FCS of Russia. The order No 372 (2013, March 1). Retrieved from http://www.pravo.gov.ru

11. URL: http://www.pravo.gov.ru

12. Federal Law No 212-FZ (2015, July 13).

13. http://www.pravo.gov.ru

14. Resolution of the Government of the Russian Federation No 975 http://www.pravo.gov.ru

15. V. Korostelev. Sravnenie sistemy predvaritelnogo informirovania tamogenny organov s mehanizmom "edinogo okna" (2017, September 18).

16. O predvaritelnom informirovanii na morskon transporte (2017, February 10). Retrieved from http://issa.ru/news/2017/02/10/news_3866.html

17. URL: https://customsexpert.ru/articles/kps-portal-morskoy-port-ot.htm

18. Order of the Government of the Russian Federation No 1125-r (2012, June 29) Retrieved from http://www.pravo.gov.ru

19. URL: http://www.tks.ru/reviews/2017/12/28/02 